\title{
A review on buildings energy consumption in Russia: educational buildings
}

\author{
Aleksandr Lanko $^{1 *}$, Francisco Jose Sanchez de la Flor ${ }^{2}$, and Tamara Narezhnaya ${ }^{3}$ \\ ${ }^{1}$ Peter the Great St. Petersburg Polytechnic University, Polytechnicheskaya, 29, St.Petersburg, \\ 195251, Russia \\ ${ }^{2}$ UCA (University of Cadiz), Centro Cultural Reina Sofía, C/ Paseo Carlos III, nº 9, Cádiz, 11003, \\ Spain \\ ${ }^{3}$ Moscow State University of Civil Engineering, Yaroslavskoye shosse, 26, Moscow, 129337, Russia
}

\begin{abstract}
To understand the importance of implementing energy-saving technologies in educational buildings, it is necessary to assess current energy consumption. The main goal of the article is to show the level of energy consumption of educational buildings in Russia. The main method of the study is to collect information from various sources and to analyze it in order to identify the factors that have the greatest impact on the volume of energy consumption. The collected information for Federal districts is compared with each other, and the average data for Russia is compared with figures for similar buildings in the European Union and North America. A comparison of the resulting data for the Federal districts of Russia shows that climate is one of the most important factors affecting energy consumption. As a result, according to different estimates, the total energy consumption in educational buildings is from 240 to $400 \mathrm{kWh} / \mathrm{m} 2$. It is one of the highest in comparison with developed countries of the European Union and North America.
\end{abstract}

\section{Introduction}

Within the scientific community, there is growing agreement that climate change is real and a threat to humankind [1]. Climate change is one of the major challenges of the 21st century requiring global strategies for efficient energy supply, sustainable use of resources and the reduction of greenhouse gas (GHG) emissions [2]. The comparison of energy consumption of educational buildings in Russia with the same buildings in Europe and North America shows a great potential for energy saving. Russia, like many other countries of the world, wants to ensure energy stability and security, and reduce atmospheric emissions that are dangerous to the planet and climate. To develop measures in reducing of the buildings energy consumption, first of all, it is necessary to have high-quality, modern, comparable and most detailed diversified consumption data. These data should reflect the distinctive characteristics of various human activities in relation to energy use. The more detailed and diverse the data will be presented, the easier it will be to find not only sources of increased consumption, but the reasons for this consumption. Unfortunately, very few

${ }^{*}$ Corresponding author: alexandr.lancko@yandex.ru 
studies are conducted in Russia on energy consumption in buildings. The most important contribution was made by Center for Energy Efficiency (CENEF) headed by I. A. Bashmakov and The Institute of urban economics. Researchers from these centers have conducted significant studies in the field of building consumption, but according to their own statements, the data obtained are not accurate due to the small amount of input information and require clarification. For a long time, the main tool for tracking of energy consumption by type of energy resource and main sector was the Energy balance of countries. In Russia, the Fuel and Energy Balance is practically the single, most unified instrument. According to data from energy balances, aggregate indicators are calculated, such as total energy consumption per person or total final consumption per unit of gross domestic product (GDP). The aggregated indicators have the advantage that they are easily and quickly available, in simple numbers they allow us to evaluate and compare the total energy consumption both in time and in space. However, their practical applicability is limited and in case of improperly use, they can be misleading. Many factors influence on the indicators: climate, thermal characteristics of buildings, consumer behavior and many others. Climate in Russia is one the main factors, and this article will show the influence of climate factors on the final consumption of educational buildings.

The main purpose of this article is to collect and analyze data of the consumption in educational buildings of Russia.

\section{The main sources of information}

Specific consumption of energy resources in the Russian Federation for this sector are calculated on the basis of official statistical reporting: № VPO-2 "Information about material-technical and information base of financial-economic activity of educational organizations of Higher education" [3], SPO-2 "Information about material-technical and information base, financial and economic activity of a professional educational organization" [4] and OO-2 "Information about the material and technical and information base, financial and economic activity of a General education organization" [5]. On the basis of these data, various ministries of the Russian Federation prepare energy reports. This paper uses reports from the Ministry of Energy [6-11] and the Ministry of Economic Development [12-16]. Methods for calculating the indicators of Ministries differ, as a result of their data may differ. The paper also presents data from energy declarations [17] provided in the GIS "Energy Efficiency" (State information system in the field of energy saving and improving energy efficiency).

\section{Types of educational institutions and their differences in energy consumption}

Among Russian state institutions, one of the largest consumers of energy resources are educational institutions (Universities, technical schools, schools, preschool institutions, etc.).

According to the data for 2008, All educational institutions have the following classification [Error! Reference source not found.]:

1. Preschool educational institutions - 45730 units.

2. General education institutions (schools) - 53532 units.

3. Educational institutions of primary vocational education - 3325 units.

4. Educational institutions of secondary vocational education - 2535 Units

5. Educational institutions of higher education (institutes, academies, universities) - 660 units 
The previous classification of educational buildings primarily affect the consumption of electrical energy for lighting and for different types of equipment. The requirements for the temperature regime for heating in educational buildings are practically the same. Thus, the consumption of heat energy in educational buildings practically does not depend from the type of educational institution (classification). In this part we will pay attention only for electric non heating energy consumption. The main factors affecting the electricity energy consumption for equipment of educational buildings are: type of a special equipment which is used in education process, availability of restaurants, availability of electric boilers for hot water production, availability of gyms and swimming pools.

\subsection{Higher education institutions}

The study of energy balances of higher education institutions shows that the determining factor is the consumption of thermal energy up to $70 \%$, followed by the consumption of electricity up to $40 \%[19]$. For technical institutions of higher education, lighting and laboratory equipment account a significant share of the balance of electricity consumption, followed by electricity consumption in restaurants, and in third place - electricity consumption of computer and office equipment. In humanitarian institutions, the most significant share in the balance of electricity consumption is provided by lighting and equipment in canteens. A study of the lighting system of Universities shows that their energy consumption is also very high. The main reasons for this are: a large proportion of incandescent lamps, the use of inefficient fluorescent lamps, wear of the lighting part of lighting devices, the use of start-up control equipment in fluorescent lamps with large power losses, bad lighting automation.

\subsection{Secondary and primary vocational education institutions}

The main consumers of electricity are: lighting systems, refrigerators, electric heaters, computers and office equipment, laboratory installations and electrical equipment of workshops. In the workshops electrical equipment depends on the training profile of specialists. These can be machine tools, welding machines, electric sewing machines, etc.

The energy consumption by these institutions is:

- for electricity: from 27 to $40 \%$;

- for heat energy: from 60 to $73 \%$; [19]

\subsection{Schools}

The main factors affecting electricity consumption in schools are: number of working hours, type of lighting; type of kitchen equipment (electric or gas), availability of hot water. The analysis of the influence of various factors on the value of the specific installed power of lighting is carried out. The consumption for lighting depends on the type of room and is (for fluorescent lamps): - for classrooms no more than $15 \mathrm{~W} / \mathrm{m}^{2}$; - for other spaces no more than $3 \mathrm{~W} / \mathrm{m}^{2}$. Thus, the value of the specific installed lighting power depends on the proportion of the area of classrooms in the total area of the school.

The balance of energy consumption of schools is: electricity- from 15 to $46 \%$, thermal energy - from 54 to $85 \%$. [19]

\subsection{Preschool educational institution}

In preschool educational institutions, the inside temperature (near $20 \mathrm{C}$ ) [20] is more 
strictly controlled than in other educational institutions, so the specific consumption of heat energy in them is higher. The balance of energy consumption by preschool is: electricity from 8 to $30 \%$, heat energy - from 70 to $92 \%$ [19].

\section{Analytical data}

The study presents data on energy consumption of buildings in educational government sector which is one of the main consumers of energy among buildings of public government organizations. Due to the different specifics and functional purpose of buildings, data will be presented only on heat consumption (heating and hot water) and electricity consumption (lighting and other electrical equipment). The data shows information about buildings that receive heat and electricity from an external source.

This article presents data on the Russian Federation for Federal districts that are not subjects of the Russian Federation and were created [21] for ease of management in 2000.

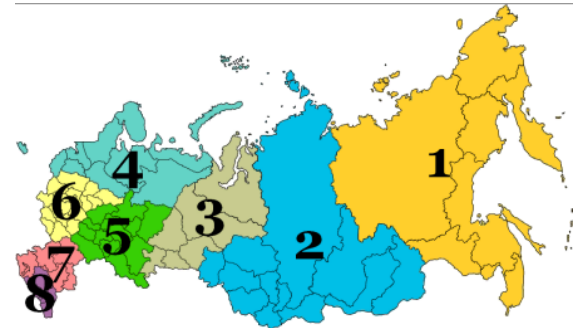

1.Dal'nevostochnyj Federal District (DFD)

2. Sibirskij Federal District (SFD)

3. Ural'skij Federal District (UrFD)

4. Severo-Zapadnyj Federal District (SZFD)

5. Privolzhskij Federal District (PFD)

6. Central'nyj Federal District (CFD)

7. YUzhnyj Federal District (YFD)

8. Severo-Kavkazskij Federal District (SKFD)

Fig. 1. Federal districts in Russia Federation

\subsection{Heating}

HVAC systems in buildings have the purpose to ensure a certain level of thermal comfort, but in general this objective implies a big energy consumption [22]. The heating sector in Russia accounts for a third of the country's primary energy consumption. In 2010 International Energy Agency estimate Russia's heat consumption is equal to the total final energy consumption of Mexico [23]. About 78\% is generated by district heating, a system of transmitting heat, usually in the form of hot water, from a centralized boiler or cogeneration plant through a network of pipes [24]. As acknowledged by the Russian Government, about $70 \%$ of Russian district heating infrastructure needs to be replaced in the near future $[25,26]$. The average heat boiler efficiency is about $73 \%$ [27]. The combined consumption of residential, commercial and public consumers is $33 \%$ of all heat consumption [28].

The official reports of the Ministry of Energy of the Russian Federation and the Ministry of Economic Development of the Russian Federation provide data on the expenditure of thermal energy for the supply of state and municipal buildings. It is not net energy consumption, but the heat energy released from the Central boiler houses for the needs of buildings. This situation arose as a result of the fact that many state and municipal buildings are not equipped with metering devices for incoming energy. Thus, data on the final energy consumption of most buildings can only be obtained by calculation. This is especially true for thermal energy. In 2017, the average percentage of heat input metering devices in state and municipal buildings slightly exceeded 50\%. Full data on the availability of metering devices for the Federal districts of the Russian Federation from 2014 to 2017 are presented below. 


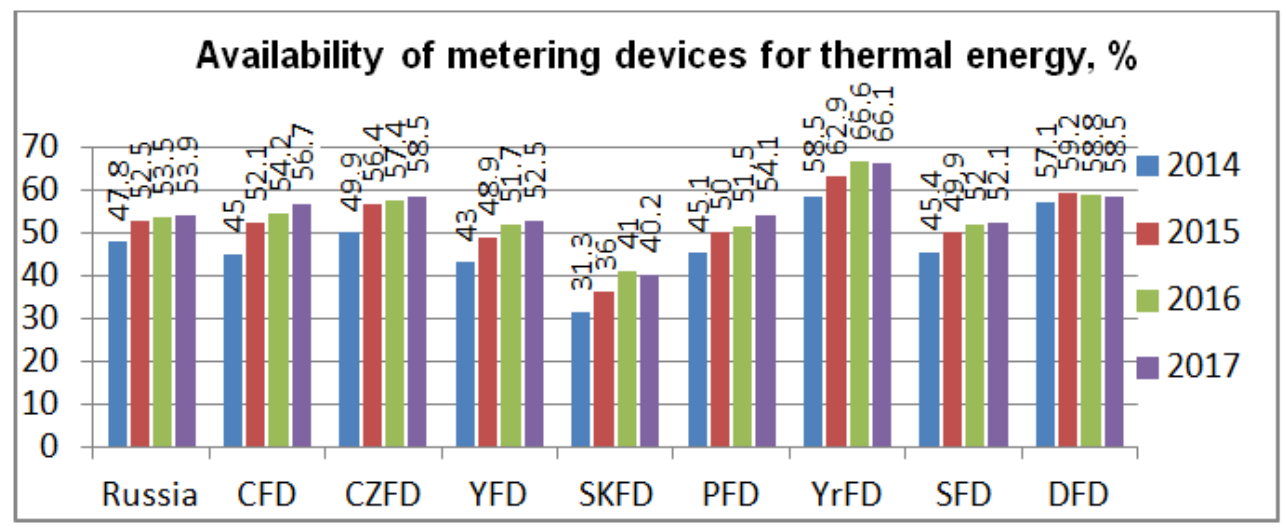

Fig. 2. Availability of metering devices for thermal energy inputs of budget sector organizations, $\%$. Source: GIS "Energy Efficiency" (State information system in the field of energy saving and improving energy efficiency).

Despite the fact that the trend of installation of metering devices is positive, their number is clearly not enough. Many buildings simply can't control heat consumption, manage consumption effectively, and are not sufficiently interested in reducing of consumption. This is evidenced by the almost complete absence of individual automatic heating control (IAHC) depending on weather conditions. On average, just over 5\% of state and municipal buildings are equipped with such automation in Russia.

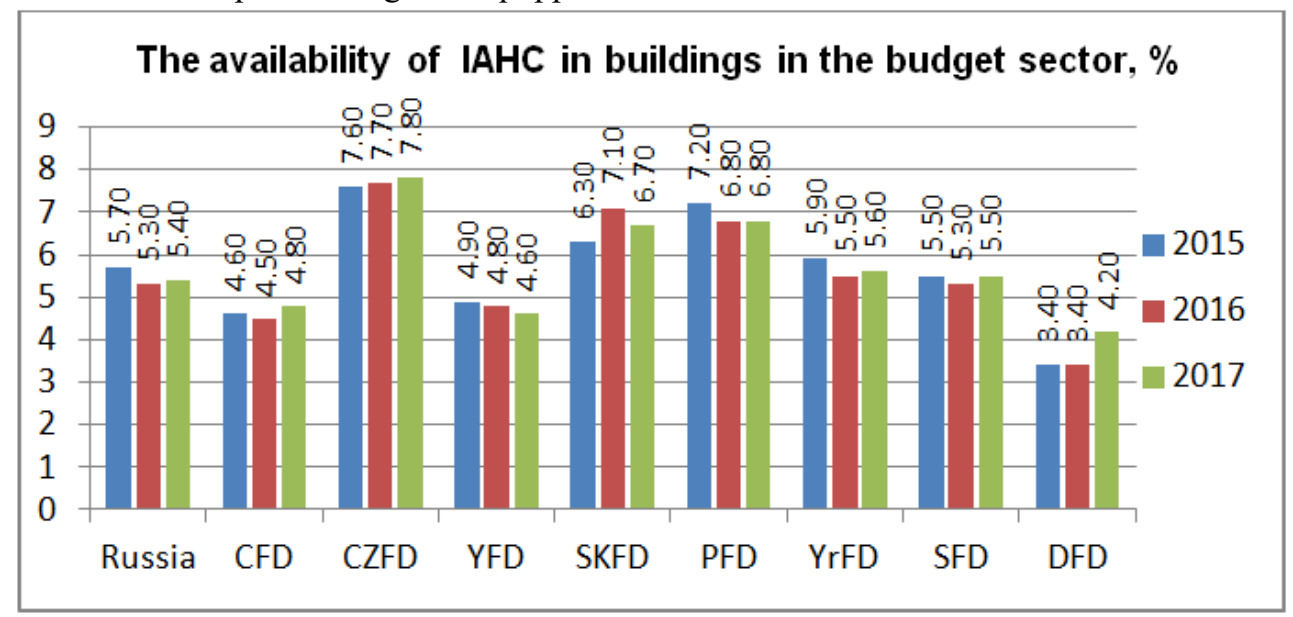

Fig. 3. The availability of IAHC in buildings in the budget sector, percent of the total number, $\%$. Source: GIS "Energy Efficiency" (State information system in the field of energy saving and improving energy efficiency).

Due to the limited data on the actual final consumption of state and municipal buildings, the Ministry of economic development publish data on the heat "released" to buildings on the basis of Rosstat [29] data. 


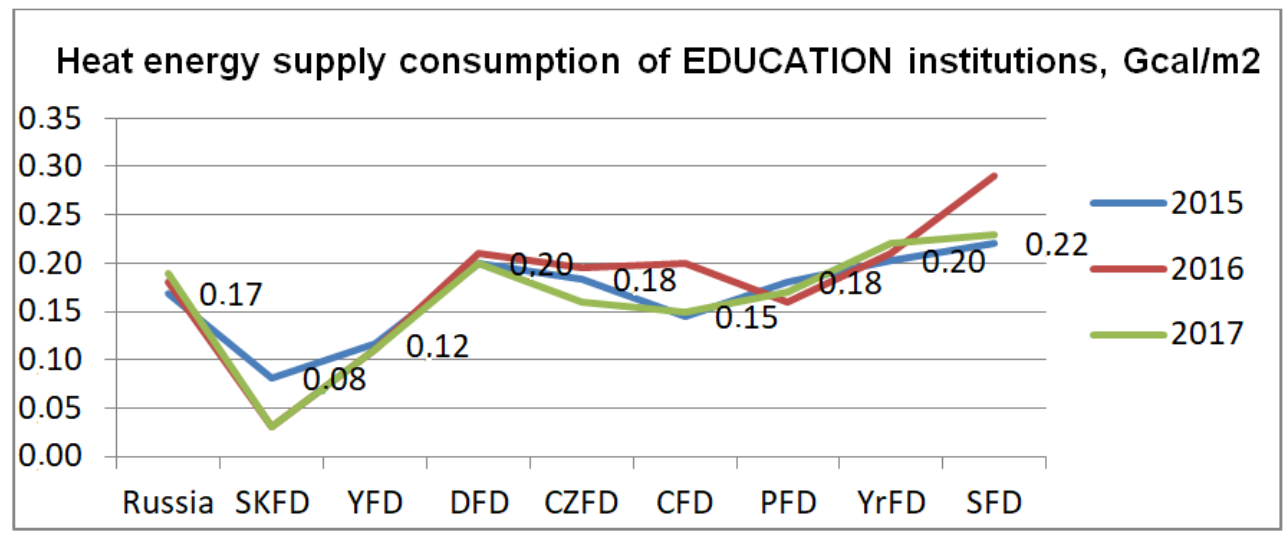

Fig. 4. Heat energy supply consumption of state and municipal EDUCATION institutions according to Rosstat. Source: The Ministry of economic development, The Ministry of Energy, Gcal / $\mathrm{m}^{2}$

In this graph, the Federal Districts are arranged in ascending order from the district with the coldest climate to the warmest. The graph shows the impact of climate on energy consumption for heating in educational buildings. The lowest heat energy consumption in Severo-Kavkazskij Federal District is directly related to the lowest number of heating degree days (HDD) in this region. HDD characterize heat deficiency and calculated by summing the absolute deviations of the average daily air temperature from the selected base temperature. Detailed information about HDD is provided in the next part of the article.

For a simplified calculation of net consumption, it is necessary to subtract the amount of losses for the transportation of heat energy.

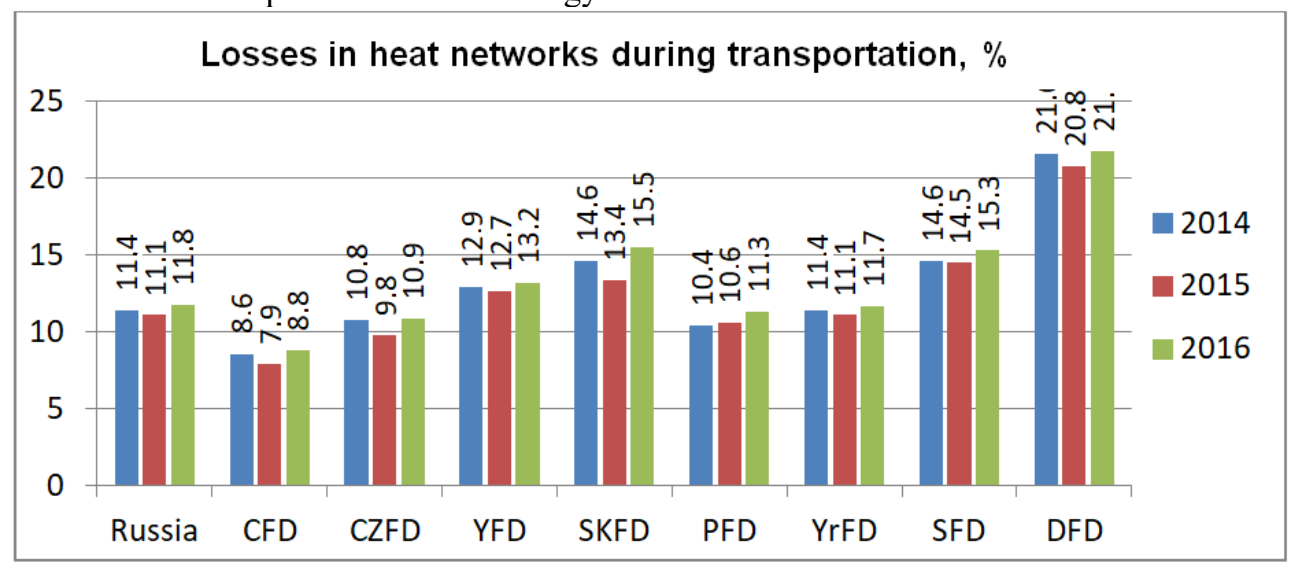

Fig. 5. Losses in heat networks during transportation. Source: Rosstat, form 1- TEP, \%

The average figures for Russia are slightly more than $10 \%$. Maximum in the Dal'nevostochnij Federal district, which is associated not only with a cold climate, but also with a large physical wear of heat networks. The presented data allow us to calculate the net consumption of educational buildings. 


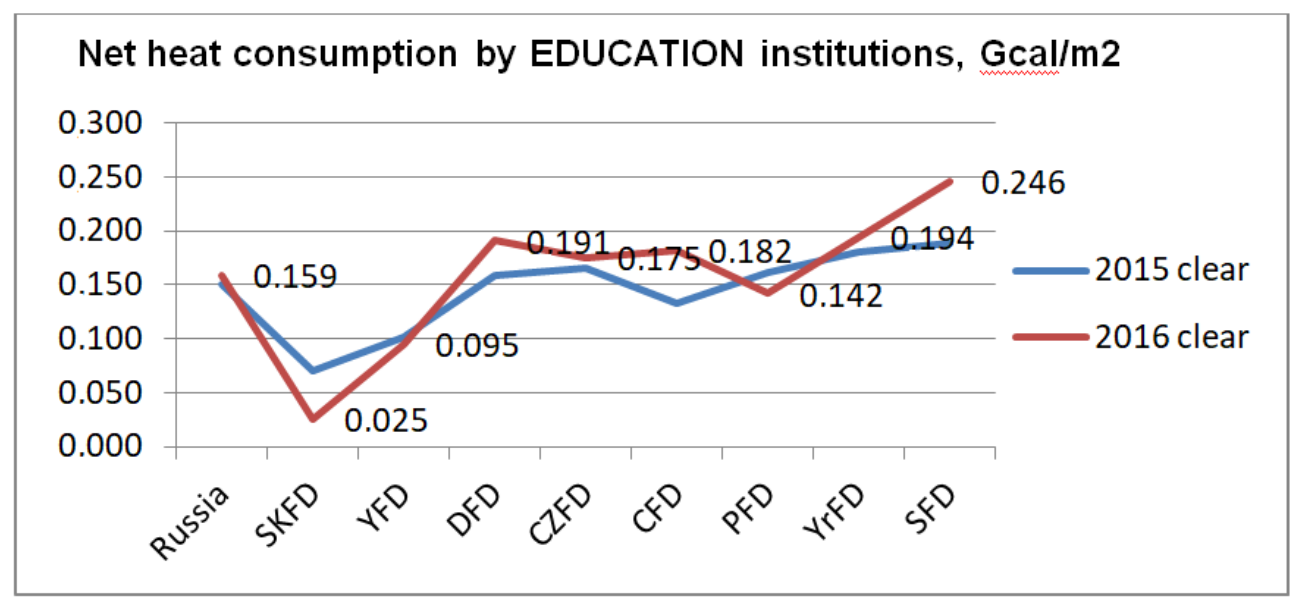

Fig. 6. Net heat consumption by EDUCATION institutions (calculated), Gcal/sq. m.

What is the reason for such a large consumption of thermal energy by buildings in the educational sector? As shown above, it is climate, insufficient accounting for energy consumption and weak motivation of educational institutions.

\subsection{Impact of climate and HDD factor.}

The climate has a significant impact on energy consumption in the country. In Russia, where almost $60 \%$ of the final energy is spent on heating, taking into account the influence of climate is especially relevant. The most common climatic indicators of energy consumption for space heating and cooling (energy consumption indices) are the characteristics of heat deficiency (HDD heating degree day) or cold deficiency (CDD cooling degree day), which are calculated for the whole year or a certain period of the year by summing the absolute deviations of the average daily air temperature from the selected base temperature. The issue of choosing the base temperature, as well as the methodology for calculating energy consumption indices, is widely discussed and may vary by country [30]. The baseline temperatures for HDDs and CDDs in Europe are $15.5{ }^{\circ} \mathrm{C}$ and $22{ }^{\circ} \mathrm{C}$ [31,32]. In Russia, the base HDD temperature is $+18.3{ }^{\circ} \mathrm{C}$, which is considered as a comfort. It is not entirely correct to use HDD data from different countries when comparing, without correction of the base temperature. Another complicating factor in calculating and using the average HDD is the wide variety of climatic zones and the uneven distribution of population in Russia. This problem also exists for many other countries. When comparing the regions of Russia, regional HDDs should be used. For Russia, the average HDD is 5000C. The impact of CDD in the whole country is quite low. The reason is the cold climate and the small number of regularly used air conditioners. Thus the influence of the CDD factor in Russia on the energy consumption of educational buildings is extremely insignificant.

The diagram below shows the impact of the HDD on net consumption for heating of public and municipal buildings in education sphere. 


\section{Impact of the HDD on heat consumption in educational buildings}

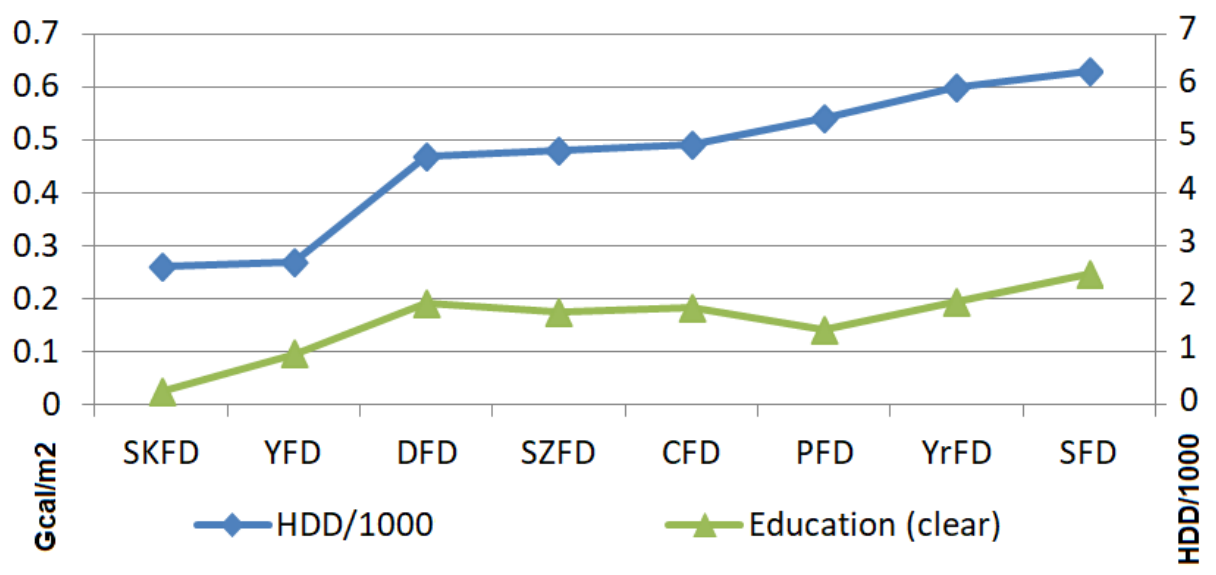

Fig. 7. The impact of the HDD on heating consumption in educational buildings, Gcal $/ \mathrm{m}^{2}$

\subsection{Electricity consumption}

The number of electric energy metering devices is higher than that of heat. The average figure for the Russian Federation is about $70 \%$

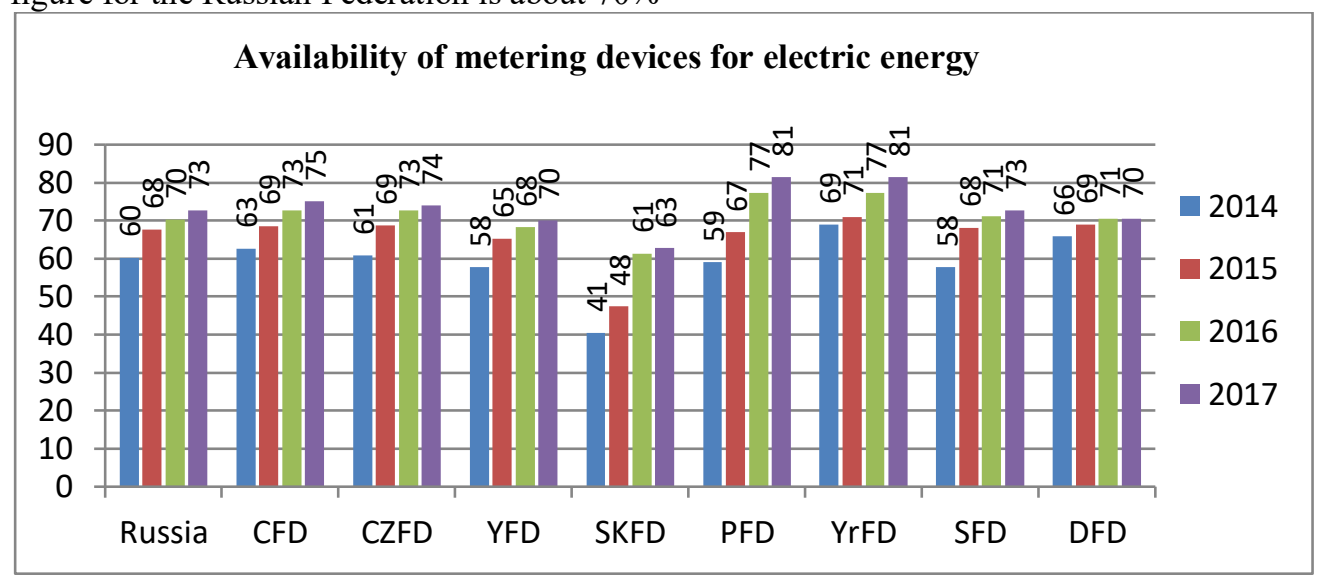

Fig. 8. Availability of metering devices for electric energy consumption of organizations in the budget sector according to GIS "Energy Efficiency" (State information system in the field of energy saving and improving energy efficiency), \%. Sourse: Ministry of economic Development 2017.

But, as in the case of thermal energy, insufficient attention is paid to reducing the consumption of electric energy in educational buildings. 


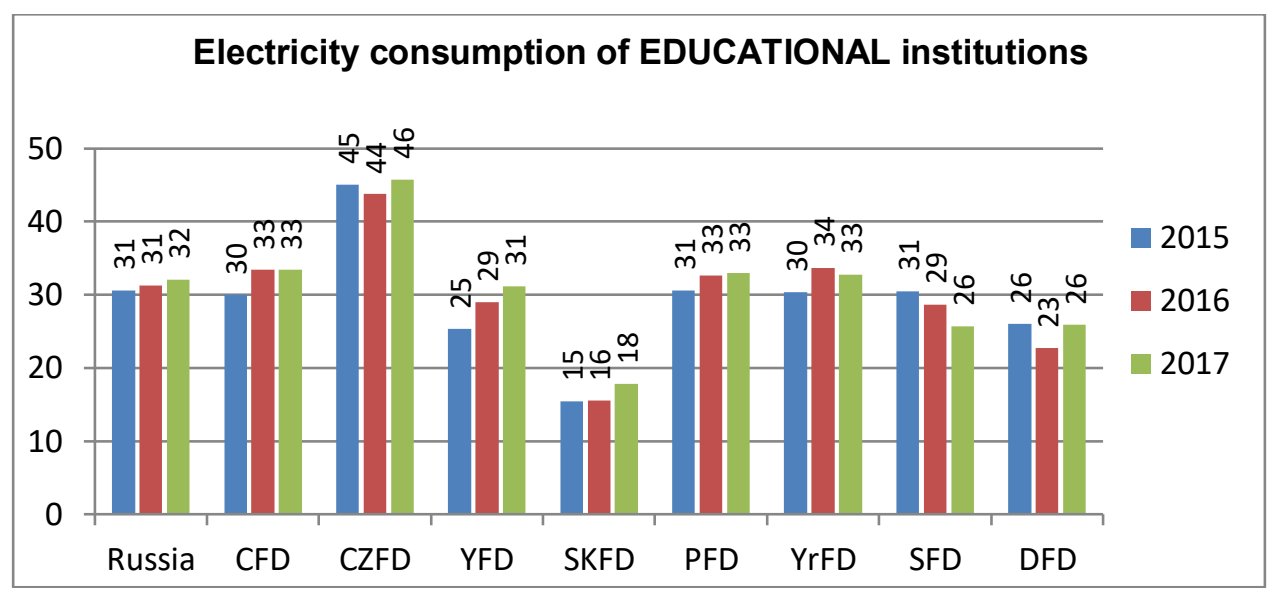

Fig. 9. Supply Electricity consumption of EDUCATIONAL buildings according to Rosstat, $\mathrm{kWh} / \mathrm{m}^{2}$ per year. Source: Ministry of energy 2015, Ministry of economic Development 2016-2017

In the case of electric energy, the influence of climate in the situation of the use of heat energy from the outside is practically not apparent. The main factors that determine the consumption of electric energy are the type of lamps for lighting the building and the type of installed equipment. The impact of having a large amount of equipment can be seen when comparing the electrical energy consumption in health and education buildings. Electricity costs in health care buildings are almost double that of educational buildings.

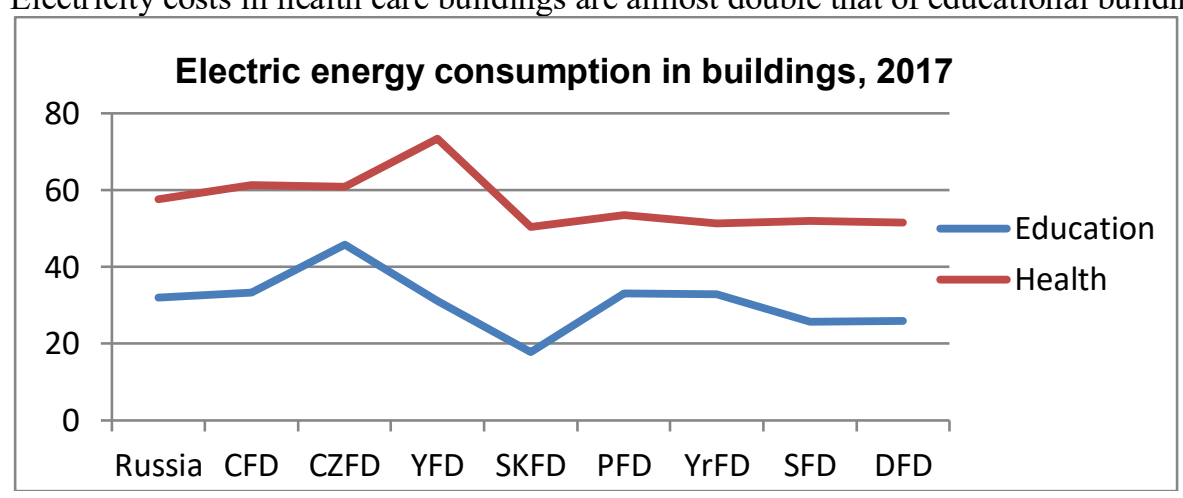

Fig. 10. Comparing electric energy consumption: health and education buildings, $\mathrm{kWh} / \mathrm{m}^{2}$ per year

\subsection{Lighting}

Electric energy consumption for lighting in public, educational and state buildings is about $12000 \mathrm{GWh} /$ year [33]. This indicates a high potential for saving electrical energy. Of course, replacing non effective incandescent and fluorescent lamps for high-performance led lamps is one of the main activities for saving energy in buildings. In Russia, the use of old incandescent lamps and the use of modern led lamps is currently quite high in educational buildings. 
Distribution of lighting types in state and municipal buildings, 2016

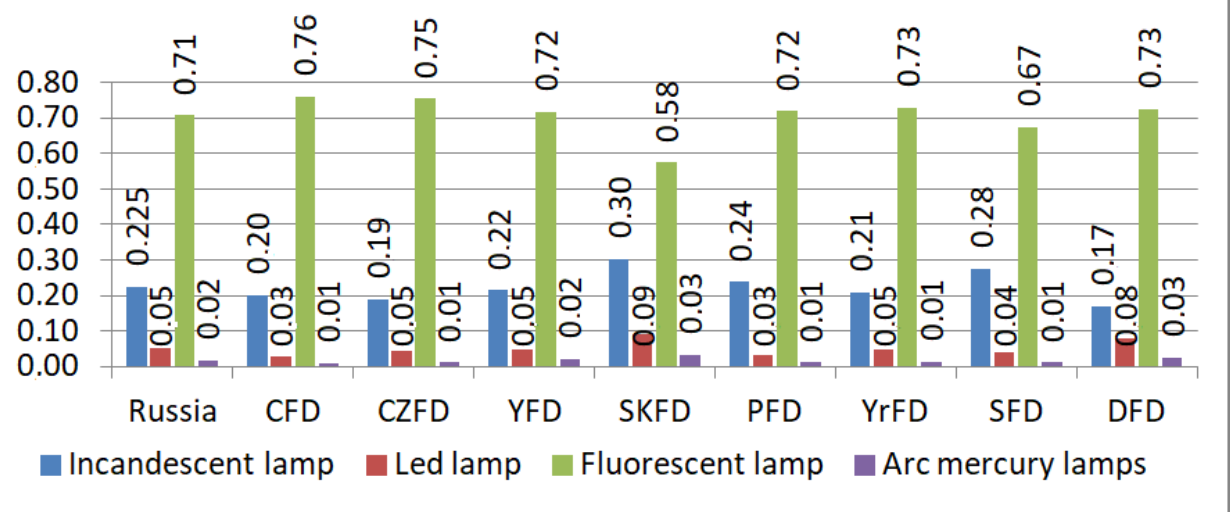

Fig. 11. Distribution of lighting types in state and municipal buildings 2016, \%

This graph shows that the share of incandescent lamps is almost a quarter of the total number. And the share of modern led lamps does not exceed 5\%. Fluorescent lamps with a share of more than $70 \%$ are also not highly effective. The use of start-up control equipment in fluorescent lamps provide large power losses. In addition, fluorescent lamps create uncomfortable light, noise, and often require frequent replacement. In the field of education, lamps are used daily for 10-12 hours, so there is also a great potential for saving energy by controlling lighting systems.

\section{Energy efficiency in educational institutions in comparison}

This section will compare the energy consumption of educational institutions In Russia and in some countries of the European Union and North America.

Compared with the countries of the European Union and North America, educational buildings in the Russian Federation consume the most energy. This applies equally to the consumption of heat and electricity for lighting and different equipment. The difference can be seen when comparing the heat consumption and the total consumption of buildings. Center for Energy Efficiency (CENEF) [34] conducted a research [35] on energy consumption in public buildings in Russia compared to similar buildings in other countries. The primary data for this study is shown in Figure 11. 


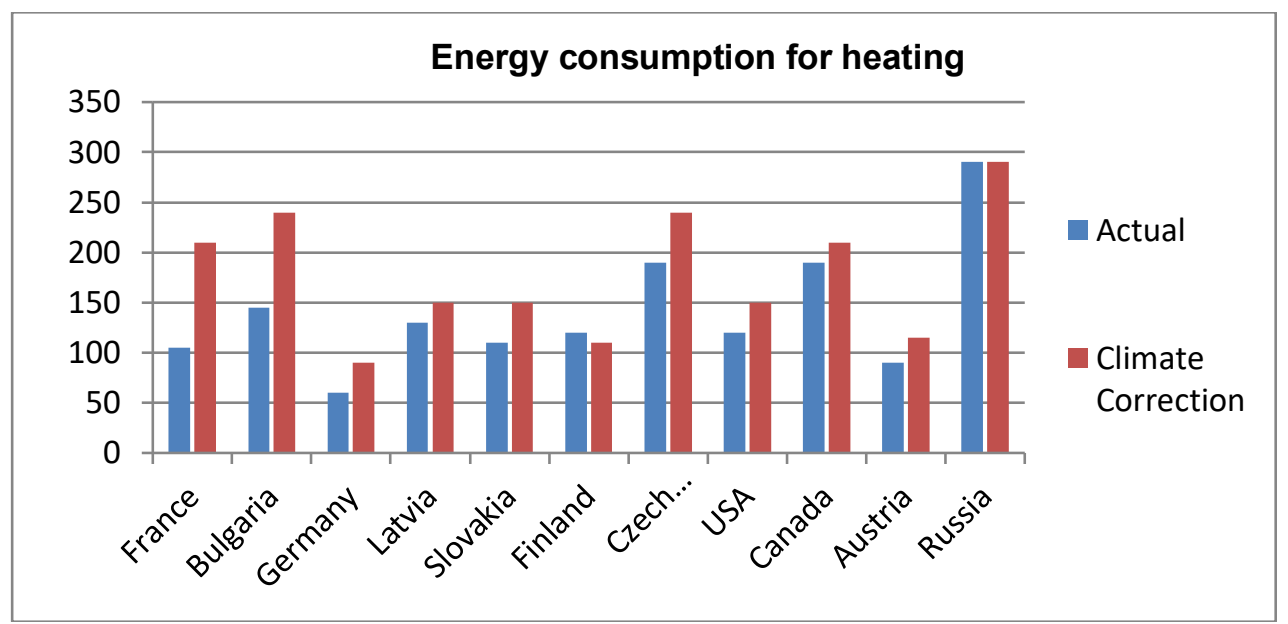

Fig. 12. Energy consumption for heating of educational buildings in some countries, $\mathrm{kWh} / \mathrm{m}^{2}$ per year. Source: CENEF

The graph shows not only the actual consumption of heat energy in educational buildings, but also these indicators with climate correction. After the correction, the difference in the level of consumption decreased, but still energy consumption in Russia remains the highest among the compared countries. Leader in energy efficiency Germany is ahead of Russia in three times. These figures indicate a huge potential for saving heat energy in educational buildings in the Russian Federation. When comparing total energy consumption (without climate correction), the difference in energy consumption is even more significant (Figure 12).

The total energy consumption in the Russian Federation is estimated by CENEF to be just over $400 \mathrm{kWh} / \mathrm{m}^{2}$ and roughly corresponds to the energy consumption in Canada, a country with a similar climate and a large territory. It is noteworthy that according to official data of the Ministry of Energy of the Russian Federation, data of energy consumption of educational buildings is significantly lower. If we translate the data calculated by the author on the basis of official data, we will get an approximate consumption of about $240 \mathrm{kWh} / \mathrm{m}^{2}$ for 2015 . Even taking into account the fact that CENEF experts calculated their figures before 2010, such a sharp drop in consumption is impossible. Most likely, such contradictory data arose from different methods of calculating indicators and differences in primary data. Climate correction will change this picture, but in any case, the total energy consumption in the Russian Federation remains quite large compared to the world's leading countries.

When comparing public buildings (Figure 13) in the Russian Federation, CENEF estimates that there is not much difference in total energy consumption, which is caused by a high proportion of building heating costs. 


\section{Actual total consumption}

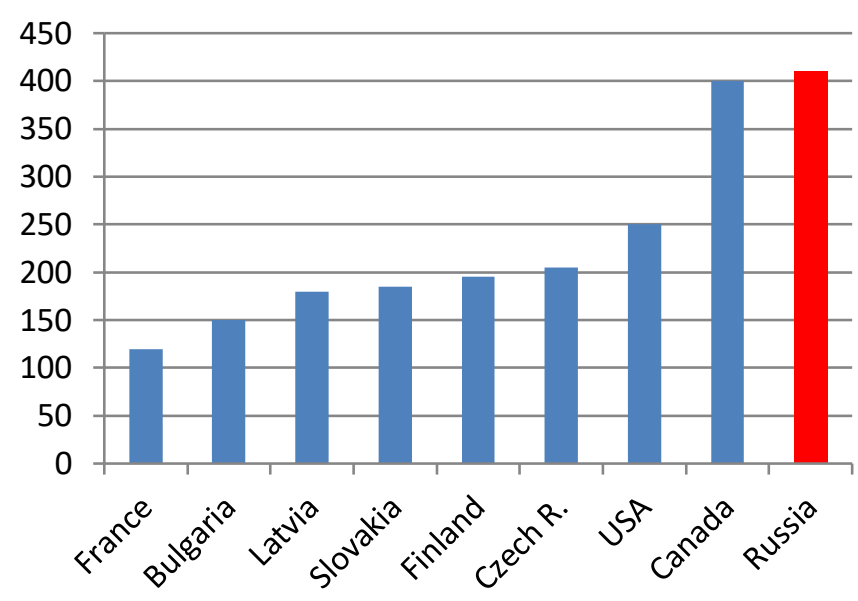

Fig. 13. Actual total consumption of educational buildings in several countries, $\mathrm{kWh} / \mathrm{m}^{2}$ per year (Source: CENEF)

\section{Total consumption}

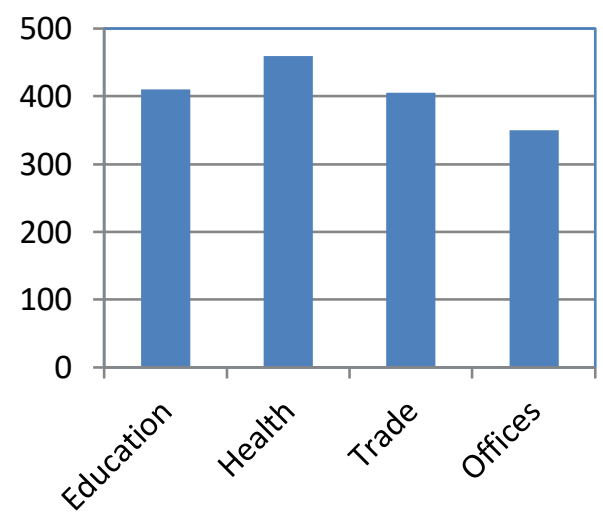

Fig.13. Actual total consumption of public buildings in Russia, $\mathrm{kWh} / \mathrm{m}^{2}$ per year (Source: CENEF)

The highest energy consumption is observed in health-improving buildings due to high levels of equipment with electrical appliances.

\section{Conclusion}

Energy consumption of educational buildings in Russia is one of the highest in comparison with developed countries of the European Union and North America. According to various estimates, the total energy consumption in educational buildings is from 240 to 400 $\mathrm{kWh} / \mathrm{m}^{2}$.

The analysis of educational institutions of different types and specializations did not reveal significant differences in the total consumption of buildings. Differences were observed only in electricity consumption, which was caused by different composition of electrical equipment. 
The consumption of thermal energy is crucial in the energy balance of educational organizations. The average net consumption was estimated at 175 to $300 \mathrm{kWh} / \mathrm{m}^{2}$ per year. The climate factor plays a significant role in the consumption of thermal energy.

The main consumers of electricity in educational buildings are lighting and canteen equipment. In lighting, the share of high-performance led lamps exceeds $5 \%$, while the share of obsolete incandescent lamps is more than $20 \%$. According to various estimates, the average consumption of electric energy is from 30 to $100 \mathrm{kWh} / \mathrm{m}^{2}$ per year.

Comparison of energy consumption of public buildings for various purposes in Russia showed a small difference in the volume of consumption. In General, the buildings of the education system in the Russian Federation have a great potential for saving energy. The main problem remains the lack of interest of the management of educational institutions and the lack of funding for the introduction of energy-saving technologies.

\section{References}

1. J.M. Salmerón, L.R. Rodriguez, et al. Sustainability, 10(11), 4082 (2018) DOI: 10.3390/su10114082

2. J. Bilbao, R. Roman, et al. Atmos. Environ, 99, 508-518 (2014) DOI: 10.1016/j.atmosenv.2014.10.005

3. Ministry of Researches and Higher Education of Russia. (Access date: 19.02.2020) URL: minobrnauki.gov.ru/ru/activity/stat/highed/index.php

4. Government statistics. (Access date: 17.02.2020) URL: www.fedstat.ru/form/10072

5. Federal Statistical Observation. (Access date: 20.02.2020) URL: podschool.ru/downloads/doc/sved_mat_baza.pdf

6. State report on the state of energy saving and improving energy efficiency in the Russian Federation in 2016. (Access date: 20.02.2020) URL: minenergo.gov.ru/modal/view-pdf/5197/76456/nojs

7. The energy efficiency rating of constituent entities of the Russian Federation (2017). (Access date: 20.02.2020) URL: minenergo.gov.ru/modal/view-pdf/5197/76616/nojs

8. The energy efficiency rating of constituent entities of the Russian Federation (2016). (Access date: 20.02.2020) URL: minenergo.gov.ru/modal/view-pdf/5197/69427/nojs

9. State report on the state of energy saving and improving energy efficiency in the Russian Federation in 2015. (Access date: 20.02.2020) URL: minenergo.gov.ru/modal/view-pdf/5197/66062/nojs

10. State report on the state of energy saving and improving energy efficiency in the Russian Federation in 2014. (Access date: 20.02.2020) URL: minenergo.gov.ru/modal/view-pdf/5197/69065/nojs

11. Forms of providing information for the rating of heat supply efficiency. (Access date: 20.02.2020) URL: minenergo.gov.ru/system/download/5197/85256

12. Ministry of Economic Development Russian Federation. (Access date: 18.02.2020) URL:

www.economy.gov.ru/material/dokumenty/gosudarstvennyy_doklad_po_energoeffekti vnosti_html

13. Ministry of Economic Development Russian Federation. (Access date: 18.02.2020) URL:

www.economy.gov.ru/material/dokumenty/gosudarstvennyy doklad po energoeffekti $\underline{\text { vnosti .html }}$ 
14. Monitoring the implementation of state programs of the Russian Federation for the I-II quarters of 2018. (Access date: 18.02.2020) URL: www.economy.gov.ru/material/dokumenty/monitoring_realizacii_gosudarstvennyh_pr ogramm_rossiyskoy_federacii_za_iii_kvartaly_2018_goda.html

15. Final report of the Ministry of economic development of the Russian Federation on the results of the analysis of the state and prospects of development of the education system for 2018. (Access date: 18.02.2020) URL: old.economy.gov.ru/minec/about/structure/depupravdelami/2019121706

16. Final report of the Ministry of economic development of the Russian Federation on the results of the analysis of the state and prospects of development of the education system for 2016. (Access date: 18.02.2020) URL: old.economy.gov.ru/minec/about/structure/depupravdelami/2017271103

17. Order of the Ministry of energy of Russia of 30.06.2014 № 401 (ed. of 11.12.2015) "On approval of the Procedure for submitting information on energy saving and energy efficiency improvement". (Access date: 13.02.2020) URL: gisee.ru/articles/documentation/56557/

18. I. P. Suslov. Statistics, 376 (2003).

19. S.A. Bugrov. PhD Thesis (2011)

20. N. Vatin. Trans Tech Publications, 953-954, 1537-1544, (2014) DOI: 10.4028/www.scientific.net/amr.953-954.1537.

21. Decree Of the President of Russia V.V. Putin, On the Plenipotentiary representative of the President of the Russian Federation in the Federal district, 849 (may 13, 2000)

22. P. Aparicio Ruiz, F.J. Sánchez de la Flor, et al. Energy and Buildings, 119, 74-84 (2016) DOI: 10.1016/j.enbuild.2016.03.023

23. IEA. World Energy Statistics 2010. OECD Publishing, Paris, (2010)

24. A. Nekrasov, Y. Sinyak, et al. Studies on Russian Economic Development, 22(1), 2030 (2011) DOI: 10.1134/S1075700711010072

25. Ministry of Energy of the Russian Federation 2010, Energy Strategy of Russia for the Period of up to 2030. Approved by Decree No. 1715r of the Government of the Russian Federation (November 13, 2009)

26. IEA. World Energy Outlook 2011. OECD Publishing, Paris (2011)

27. Energy Efficiency and Climate change mitigation. (Access date: 13.02.2020) URL: staging.unece.org/index.php?id=21782

28. A. Korppo and N. Korobova. Energy Policy, 42, 213-220 (2012) DOI: 10.1016/j.enpol.2011.11.078

29. Federal state statistics service. (Access date: 19.02.2020) URL: www.gks.ru/

30. A. R. Day, I. Knight, et al. Build. Serv. Eng. Res. Technol., 24(4), 221-228 (2003) DOI: 10.1191/0143624403bt073oa

31. M. Isaac, D. P. van Vuuren. Energy Policy, 37(2) 167-175 (2009) DOI: 10.1016/j.enpol.2008.09.051

32. Heating and cooling degree days. European Environment Agency. (Access date: 19.02.2020) URL: www.eea.europa.eu/data-and-maps/indicators/heating-degree-days2

33. GEF 2010. Project documentation. (Access date: 19.02.2020) URL: www.thegef.org/gef/sites/thegef.org/files/documents/document/10062010\%20ID3596\%20\%20-\%20\%20\%20Council\%20Letter.pdf 
34. Center for Energy Efficiency. (Access date: 17.02.2020) URL: www.cenef.ru/art_11207_114.html

35. I. A. Bashmakov. The article on the CENEF website is freely available (Access date: 17.02.2020) URL: www.cenef.ru/file/ComparisonEEfBuilding.pdf 